Article

\title{
Immunizing the Flock: How the Pandemic Court Rewrote Religious Freedom
}

\author{
Paul Baumgardner (D)
}

check for

updates

Citation: Baumgardner, Paul. 2021 Immunizing the Flock: How the Pandemic Court Rewrote Religious Freedom. Laws 10: 12. https:// doi.org/10.3390/laws10010012

Received: 23 January 2021

Accepted: 10 February 2021

Published: 17 February 2021

Publisher's Note: MDPI stays neutral with regard to jurisdictional claims in published maps and institutional affiliations.

Copyright: (C) 2021 by the author. Licensee MDPI, Basel, Switzerland. This article is an open access article distributed under the terms and conditions of the Creative Commons Attribution (CC BY) license (https:/ / creativecommons.org/licenses/by/ $4.0 /)$.
Department of Legal Studies, Belmont University, Nashville, TN 37212, USA; Paul.Baumgardner@belmont.edu

\begin{abstract}
When coronavirus began to descend upon the United States, religious freedom advocates across the country sounded the alarm that citizens' religious practices and institutions were under threat. Although some of the most extreme arguments championed by these advocates were not validated by our legal system, many were. This article explores the underappreciated gains made by religious freedom advocates before the U.S. Supreme Court over the past year. As a result of the "Pandemic Court", religious freedom in the United States has been rewritten. This promises to radically change the educational, employment, and health prospects of millions of Americans for the rest of the pandemic and long afterwards.
\end{abstract}

Keywords: religious freedom; US Constitution; First Amendment; Supreme Court; pandemic

\section{Introduction}

As the COVID-19 pandemic swept across the United States in the opening months of 2020, Republican officials and conservative leaders focused their attention on a peculiar casualty of coronavirus: religious freedom. "Allow me to be blunt about what is taking place. There is a movement in this country almost exclusively within the 'left's' dominion to wipe out organized religion; especially Christianity", wrote conservative firebrand Charlie Kirk (Kirk 2020). "The First Amendment to our Constitution guarantees us our religious liberty and we have been fighting to keep it ever since. We need some of that fight now" (Kirk 2020).

This call to arms became a common refrain on the political right, especially as religious adherents and institutions were asked to make adjustments in order to stem the spread of coronavirus. The head of the conservative Faith and Freedom Coalition lamented, "During this pandemic, we've seen disturbing examples of government officials restricting our First Amendment rights" (Posner 2020). Two conservative law professors took to the pages of the New York Times to relay what "many are asking: How long must this go on? America was founded in no small part so that people of every creed and conviction could worship without hindrance, in accordance with conscience and tradition" (McConnell and Raskin 2020a). The two scholars-Michael McConnell and Max Raskin-were quick to point out: "It is not for government officials to decide whether religious worship is essential; the First Amendment already decided that" (McConnell and Raskin 2020a).

Christian leaders and conservative journalists entered the fray to condemn governmental coronavirus responses that prioritized public health over spiritual well-being. R.R. Reno, editor of the conservative First Things journal, deemed the pandemic response to be decidedly un-Christian. "Clergy won't visit the sick or console those who mourn. The Eucharist itself is now subordinated to the false god of 'saving lives'" (Reno 2020). All the while, Americans were being forced into wearing masks-a clear demonstration of "enforced cowardice", as millions elected to "cower in place" (Sitman 2020). A fellow editor at First Things, Matthew Schmitz, elaborated on this collapse of social priorities in his March 27th article, "Church as a Non-Essential Service" (Schmitz 2020). "We are capable of taking 
prudent measures to keep our supermarkets open, but not our sanctuaries. Coronavirus has shown what we value", Schmitz mourned (Schmitz 2020, see also Perkins 2020). The pandemic was setting a precedent for national and state governments to devalue religious practices, while also ignoring the grave economic impact that forced closures would have on religious institutions.

The continuous clamor around the alleged weakening of religious rights, the discounting of religious practices, and the targeting of religious adherents led to a series of very public political promises and legal remedies. "The churches are not being treated with respect by a lot of the Democrat governors", President Donald Trump announced in May (Parke 2020). "Churches, to me, they're so important in terms of the psyche of our country", Trump told reporters, "America, we need more prayer, not less" (Parke 2020; Gearan et al. 2020). Conservative lawyers and law firms specializing in religious freedom agreed that more prayer (and litigation) was warranted, in order to stop churches from being "targeted" by the government for discrimination and from being viewed as "second-class" institutions (Galus 2020). NBC News reported in early June that "Ministers and churches, represented by conservative Christian law firms, have sued governors and other public officials not just in California, but also in New Mexico, Illinois, Kentucky, Virginia, Maryland, Kansas, North Carolina, Mississippi, Tennessee, Maine, Minnesota, Michigan, Missouri, Connecticut, Nevada, and Oregon, claiming that stay-at-home orders and safer-at-home restrictions violate their religious freedom rights" (Posner 2020).

Several of these religious freedom crusades received support from the federal government (Armour 2020). United States Attorney General Bill Barr released a public statement that expressed worry about the growing discrimination facing religious institutions: "The United States Department of Justice will continue to ensure that religious freedom remains protected if any state or local government, in their response to COVID-19, singles out, targets, or discriminates against any house of worship for special restrictions" (United States Department of Justice 2020). Barr promised that the Department of Justice would look into allegations of discrimination against religious adherents. "Religion and religious worship continue to be central to the lives of millions of Americans. This is true more so than ever during this difficult time", the Attorney General declared (United States Department of Justice 2020).

While the pandemic spread during the spring and early summer, and the number of coronavirus-related deaths rose within the United States, Republican officials and conservative leaders beat the drum of religious freedom. But it initially appeared that these advocates were fighting a losing battle, especially after the U.S. Supreme Court denied several appeals that called for churches to reopen (South Bay United Pentecostal Churc; et al. v. Gavin Newsom 2020; Calvary Chapel Dayton Valley v. Steve Sisolak 2020). As a result of the political right's perceived failure, many commentators lost interest in this constitutional kerfuffle.

This dwindling attention paid the political right's push for religious protections amidst the pandemic represents a serious oversight. Political scientists and legal commentators have not recognized how religious freedom advocates became political beneficiaries of the pandemic, largely through decisions handed down by the U.S. Supreme Court in its 2019-2020 term. This article explains the actions of the "Pandemic Court", and how it has successfully rewritten religious freedom within the United States.

While onlookers focused on the hot-button June 2020 cases before the Court-which included legal disputes surrounding President Trump's taxes, Deferred Action for Childhood Arrivals, and abortion-the Pandemic Court handed down several decisions that significantly extended religious protections. These decisions will have serious consequences for millions of religious and irreligious Americans during the pandemic. For, as employment, healthcare, and education have grown increasingly precarious for many Americans, four of the Pandemic Court's decisions-in Bostock v. Clayton, Espinoza v. Montana Department of Revenue, Little Sisters of the Poor Saints Peter and Paul Home v. Pennsylvania, and Our Lady of Guadalupe School v. Morrissey-Berru-pave the way for religious freedom claims (and 
exemptions) that will dramatically affect the provision of employment, healthcare, and education across the country.

The following sections will not insist that particular justices engaged in unusually sinister or historically unprecedented behavior when they ruled in ways that benefitted religious freedom advocates. In fact, it is not clear whether the Pandemic Court consciously contorted itself (or its case law) in order to uniquely reward religious freedom advocates during the pandemic or set them apart as an especially deserving group because of COVID19. Nor will it be proven —à la critical phenomenology—that specific justices were biding their time, patiently lying in wait for a legal pretext to exploit for their own pet causes or secret theocratic desires (Kennedy 1986; Vermeule 2020).

Instead, the Pandemic Court's decisions highlight how our current public health crisis coincided with a special set of cases-cases that presented a perfect opportunity for the advancement of religious freedom advocates' longstanding goals. ${ }^{1}$ The Court's decisions are particularly noteworthy because the justices did elect to rule in ways that advanced those goals or supplied clear pathways for advancement in future litigation, in spite of the pandemic-specific risks of ruling in the interest of religious freedom advocates.

\section{Religious Freedom Advocates in American Politics}

Before delving into the Pandemic Court's four decisions, it is important to clarify that the lessons these decisions provide represent more than just seasonal trends on the U.S. Supreme Court or narrow legal developments strictly related to COVID-19. This article fits within —and extends-a rich and developing field of research within American social science. Recent works, such as Bennett (2017), Lewis (2017), Baumgardner and Miller (2019), Waltman (2019), and Hollis-Brusky and Wilson (2020), have investigated the role of religious freedom advocates-especially on the Christian right—in remaking state and national laws, changing the complexion of American laws schools and the legal profession, reshaping our party system, and recentering religion in the public sphere over the past forty years. The recent rewriting of religious freedom under the Pandemic Court illustrates just one weighty piece of this broader, generational story of political involvement and institutional development.

The courts maintain pride of place within this field of research, for religious freedom advocates have turned increasingly to the judiciary in order to have their political agendas vindicated and strengthened. Even resorting to the courts for religious protection during periods of public health crisis has precedent within American law. In Jacobson v. Massachusetts, the Supreme Court was tasked with ruling on a potential religious exemption to a mandatory vaccination law (Jacobson $v$. Massachusetts 1905). In order to curb the spread of smallpox, the state of Massachusetts authorized cities and townships to require their citizens to be vaccinated. When the city of Cambridge elected to require smallpox vaccinations, a local pastor-Henning Jacobson-refused to be vaccinated. Jacobson did not believe that the government could force him to be vaccinated. He viewed such a mandatory medical measure to be unconstitutional violation of his basic freedoms. However, the Supreme Court ruled 7-2 against Jacobson, finding that the mandatory vaccination law represented a legitimate use of Massachusetts' police powers. ${ }^{2}$

More than a century later, the Supreme Court would be more accommodating of religious adherents' concerns. As we will see in the pages ahead, the boundaries of religious freedom expanded during a period of public health crisis and social unrest. The actions of the U.S. Supreme Court in its 2019-2020 term clearly demonstrate how the goals

1 See (Pierson 2004) on the importance of both timing and sequencing to institutional decision-making and American political development.

2 "This court has more than once recognized it as a fundamental principle that persons and property are subjected to all kinds of restraints and burdens, in order to secure the general comfort, health, and prosperity of the State, of the perfect right of the legislature to do which no question ever was, or upon acknowledged general principles ever can be, made so far as natural persons are concerned. The possession and enjoyment of all rights are subject to such reasonable conditions as may be deemed by the governing authority of the country essential to the safety, health, peace, good order and morals of the community. Even liberty itself, the greatest of all rights, is not unrestricted license to act according to one's own will. It is only freedom from restraint under conditions essential to the equal enjoyment of the same right by others. It is then liberty regulated by law" (Jacobson v. Massachusetts 1905, p. 26). 
of modern-day religious freedom advocates were furthered in this moment of national instability and why these goals portend greater instability for millions of Americans.

\section{Little Sisters of the Poor}

One of the most impactful decisions that the Pandemic Court handed down in 2020 was Little Sisters of the Poor Saints Peter and Paul Home v. Pennsylvania (2020). This case concerned the legality of several religious exemptions that the Trump administration had granted, in order to excuse a greater number of employers from the contraceptive mandate within the Patient Protection and Affordable Care Act of 2010 (ACA).

Following the passage of the ACA, the Health Resources and Services Administration (HRSA) located within the U.S. Department of Health and Human Services began setting guidelines for the basic medical coverage that employers had to provide under the ACA. These guidelines, released in 2011, "included the contraceptive mandate, which required health plans to provide coverage for all contraceptive methods and sterilization procedures approved by the Food and Drug Administration as well as related education and counseling" (Thomas, pp. 3,4). After concerns were raised about the contraceptive mandate's effect on employers' religious freedoms, HRSA crafted religious exemptions for group health plans in 2011, 2012, and 2013 (Thomas, pp. 4, 5). One such exemption was the self-certification of accommodation for religious employers, which "required an eligible organization to provide a copy of the self-certification form to its health insurance issuer, which in turn would exclude contraceptive coverage from the group health plan and provide payments to beneficiaries for contraceptive services separate from the health plan" (Thomas, p. 6).

However, although this accommodation was intended to ease the concerns of religious employers, some employers-such as the Little Sisters of the Poor-took issue with selfcertification. The Little Sisters sued, arguing that this accommodation would force them to compromise their religious beliefs, because submission of the form would "directly cause others to provide contraception or appear to participate in the Departments' delivery scheme" (Thomas, pp. 6, 7). Following court cases such as Zubik v. Burwell (2016), the Obama administration continued to work with employers who were uncomfortable with the selfcertification accommodation, with the goal of achieving compromises that would provide contraceptive services to employees while also addressing employers' religious concerns.

When Donald Trump assumed the presidency in 2017, the Departments of Health and Human Services, Labor, and the Treasury radically changed their approaches to ACA exemptions; these three departments "significantly broadened the definition of an exempt religious employer" so that for-profit organizations could be exempted from the contraceptive mandate if they registered religious objections to it (Thomas, p. 10). The states of Pennsylvania and New Jersey sued, claiming that the departments had not followed the rule-making process required under the Administration Procedure Act when updating their ACA exemption guidelines. ${ }^{3}$

In resolving this dispute, the majority of the Pandemic Court sided with the Trump Administration. Conservative Justice Clarence Thomas wrote the majority opinion in Little Sisters of the Poor. In his opinion, Justice Thomas explained that "the ACA leaves the Guidelines' content to the exclusive discretion of HRSA. Under a plain reading of the statute, then, we conclude that the ACA gives HRSA broad discretion to define preventive care and screenings and to create the religious and moral exemptions" (Thomas, p. 16). Additionally, the states' concerns regarding the Administration Procedure Act were unwarranted, the majority argued, because the updated exemption guidelines put forth by the Departments of Health and Human Services, Labor, and the Treasury "contained all of the elements of a notice of proposed rulemaking as required by the APA" (Thomas, p. 23).

\footnotetext{
3 "As relevant, the States—respondents here-once again challenged the rules as substantively and procedurally invalid under the APA. They alleged that the rules were substantively unlawful because the Departments lacked statutory authority under either the ACA or RFRA to promulgate the exemptions" (Thomas, pp. 11,12).
} 
Justice Ruth Bader Ginsburg, in a dissenting opinion joined by Justice Sonia Sotomayor, decried the majority's abandonment of legal precedent and her colleagues' willingness to prioritize gratuitous employer unease over women's health. In accordance with the First Amendment of the U.S. Constitution and the Religious Freedom Restoration Act (RFRA), previous Courts had sought reasonable political accommodations and legal exemptions for religious adherents. ${ }^{4}$ But the Pandemic Court was now doing much more than balancing competing rights claims. "Today, for the first time, the Court casts totally aside countervailing rights and interests in its zeal to secure religious rights to the $n$th degree", Justice Ginsburg argued (Ginsburg, p. 1). The majority in Little Sisters of the Poor was forcing "women workers to fend for themselves, to seek contraceptive coverage from sources other than their employer's insurer, and, absent another available source of funding, to pay for contraceptive services out of their own pockets. The Constitution's Free Exercise Clause, all agree, does not call for that imbalanced result" (Ginsburg, p. 2). As a result of the Court's decision, upwards of 125,000 women could be deprived of free contraception (Ginsburg, p. 2).

\section{Our Lady of Guadalupe School}

The next two Pandemic Court decisions lie at the intersection of religion, education, and employment. The first case-Our Lady of Guadalupe School v. Morrissey-Berru (2020)concerned religious institutions' immunity from basic employment protections. After the Court's 2012 ruling in Hosanna-Tabor Evangelical Lutheran Church and School v. Equal Employment Opportunity Commission (2012), the "ministerial exception" became cemented into First Amendment jurisprudence. This exception - which was found to be required both by the Free Exercise Clause and the Establishment Clause of the First Amendment-concerns religious institutions' independence in doctrinal decisions and internal governance, and the limitations that this independence places on local, state, and national governments. The ministerial exception includes exemptions from "laws governing the employment relationship between a religious institution and certain key employees" (Alito, p. 2). "State interference in that sphere", one Supreme Court justice explained, "would obviously violate the free exercise of religion, and any attempt by government to dictate or even to influence such matters would constitute one of the central attributes of an establishment of religion. The First Amendment outlaws such intrusion" (Alito, p. 10).

But how far does the ministerial exception reach? Is any state interference in a religious institution's internal governance constitutionally permissible? In Our Lady of Guadalupe School, the Pandemic Court extended the logic of Hosanna-Tabor and imposed serious restrictions on the rights of employees working at religious institutions. The consolidated Our Lady of Guadalupe School case surrounds the end of two teachers' contracts at Catholic schools. The two teachers-Agnes Morrissey-Berru and Kristen Biel-had similar professional backgrounds and duties at their respective parochial elementary schools. Both Morrissey-Berru and Biel had received some sort of Catholic educational training, andwhile serving as teachers in their parochial schools-taught their students a religious curriculum, used Catholic textbooks in their courses, led their students in prayer, attended and participated in their schools' religious programming (such as church services and biblically-inspired school plays), and had employment contracts that explained their roles in promoting the schools' religious mission (Alito, pp. 3-9).

But the two Catholic schools' failed to renew the contracts of Morrissey-Berru and Biel. Morrissey-Berru claimed that her employer had discriminated against her on the basis of her age, and that the school wanted to fill her post with a younger instructor (Alito, p. 6). Biel claimed that her employer had discriminated against her because she had requested time off for cancer treatment (Alito, p. 9). Each of the teachers filed claims with the Equal Employment Opportunity Commission. The two Catholic schools maintained that they

4 "Congress shall make no law respecting an establishment of religion, or prohibiting the free exercise thereof". First Amendment, Constitution of the United States; also see Religious Freedom Restoration Act of 1993, Pub. L. No. 103-141, 107 Stat. 1488. 
had not discriminated against their former employees, and also that their institutions were protected from these discrimination suits due to the ministerial exception.

The Pandemic Court ruled on behalf of the two Catholic schools, deeming both Morrissey-Berru and Biel to be "ministers" covered under the ministerial exception. Writing on behalf of the majority, Justice Samuel Alito significantly widened the concept of the ministerial exception, arguing that elementary school teachers-even teachers who do not practice religion in their personal lives - can fall under the purview of the ministerial exception. The ministerial exception insulates religious institutions to a remarkable degree and constitutionally mandates "autonomy with respect to internal management decisions that are essential to the institution's central mission. And a component of this autonomy is the selection of the individuals who play certain key roles" (Alito, p. 11).

But how are employees or the courts to know who plays key roles in a religious institution? How do we know who is a minister? According to the majority in Our Lady of Guadalupe School, it is important to rely on the word of the religious institution (i.e., the employer). Justice Alito reasoned, "In a country with the religious diversity of the United States, judges cannot be expected to have a complete understanding and appreciation of the role played by every person who performs a particular role in every religious tradition. A religious institution's explanation of the role of such employees in the life of the religion in question is important" (Alito, p. 22). ${ }^{5}$ Justice Thomas's concurring opinion, joined by Justice Neil Gorsuch, went even further in stressing the necessity of deferring to religious institutions: "I write separately, however, to reiterate my view that the Religion Clauses require civil courts to defer to religious organizations' good-faith claims that a certain employee's position is 'ministerial.' ... What qualifies as 'ministerial' is an inherently theological question, and thus one that cannot be resolved by civil courts through legal analysis" (Thomas, pp. 1-2).

In her powerful dissent, Justice Sotomayor pushed back against this degree of religious deference, recognizing that the Court's holding had the potential to jeopardize the basic rights of hundreds of thousands of employees across the United States. "It risks allowing employers to decide for themselves whether discrimination is actionable", Sotomayor noted. "As a result, the Court absolves religious institutions of any animus completely irrelevant to their religious beliefs or practices and all but forbids courts to inquire further about whether the employee is in fact a leader of the religion. Nothing in Hosanna-Tabor (or at least its majority opinion) condones such judicial abdication" (Sotomayor, p. 10).

\section{Espinoza}

The second Pandemic Court decision lying at the intersection of religion, education, and employment was Espinoza v. Montana Department of Revenue (2020). The Court's decision in Espinoza was a boon for parochial schools and families with children in parochial schools, as well as for religious groups seeking greater public assistance for parochial education in their states.

The Montana legislature had recently created a program that would offer tax credits to those who contributed funds to certain scholarship organizations. The organizations were then permitted to use their funds to provide scholarships to Montanan families that sent their children to private schools. Under this program, student scholarship recipients were free to apply their awards at any "qualified education provider" (Roberts, p. 2). This new program quickly came under legal scrutiny, for the state constitution prohibited public assistance from going to religious schools. The Montana Department of Revenue stepped in and adjusted the program, so that student scholarships could only be applied at non-parochial private schools (Roberts, p. 3). Only non-parochial private schools would be considered qualified education providers.

\footnotetext{
The majority was not willing to provide any clearer advice for the lower courts, suggesting instead that they "take all relevant circumstances into account and ... determine whether each particular position implicated the fundamental purpose of the exception" (Alito, p. 22).
} 
In Espinoza, the Pandemic Court was tasked with deciding whether the exclusion of parochial schools from Montana's scholarship program constituted a form of religious discrimination that violated the First Amendment. Chief Justice John Roberts, joined by the other four conservative members of the Court, ruled that this exclusion was unconstitutional. Distinguishing Espinoza from recent precedents related to state educational scholarships being used for parochial instruction, the Chief Justice asserted: "A State need not subsidize private education. But once a State decides to do so, it cannot disqualify some private schools solely because they are religious" (Roberts, pp. 12-16, 20; see Locke v. Davey 2004). Relying on historical research-including research from the aforementioned Michael McConnell-Roberts suggested that public funds for parochial schools have a rich, and perfectly constitutional, legacy (Roberts, p. 14).

But several of Chief Justice Roberts's colleagues were willing to go much further in their condemnation of the Montana state constitution and in their safeguarding of religious education. Justice Thomas (joined by Justice Gorsuch) filed a concurring opinion, in which he pointed out the grave state of religious freedom in 2020 America. Quite simply, religious freedom is under threat: "The Free Exercise Clause, although enshrined explicitly in the Constitution, rests on the lowest rung of the Court's ladder of rights, and precariously so at that" (Thomas, p. 9). Thomas protested that Supreme Court decisions and individual justices' remarks over the years had demonstrated "hostility" for religion and for robust religious freedom protections (Thomas, pp. 6-8). This hostility included fresh and "repeated denigration of those who continue to adhere to traditional moral standards, as well as laws even remotely influenced by such standards, as outmoded at best and bigoted at worst" (Thomas, p. 8). ${ }^{6}$

First Amendment case law needed to be redirected more forcefully than the majority opinion in Espinoza permitted-redirected away from the erroneous, Jeffersonian vision of a strict separation existing between church and state. Justice Thomas claimed in his concurrence that states needed to be constitutionally permitted to accommodate-and even favor-religion. "[T]he modern view, which presumes that States must remain both completely separate from and virtually silent on matters of religion to comply with the Establishment Clause, is fundamentally incorrect", Thomas contended. "Properly understood, the Establishment Clause does not prohibit States from favoring religion. They can legislate as they wish, subject only to the limitations in the State and Federal Constitutions" (Thomas, p. 3).

Justice Alito's concurring opinion also registered worries about the American political system malfunctioning and working to the detriment of religion. Far from envisioning an overextension of religious freedom claims following Espinoza, Alito spent his concurrence focusing on the historical obstacles that remained in the way of the faithful. Justice Alito's opinion was especially notable for its detailed description of anti-Catholicism within the United States and the longstanding scourge of Blaine Amendments (Alito, pp. 2-13). These nineteenth-century changes to state constitutions-such as the anti-aid provision in the Montana constitution-have perpetuated religious discrimination for generations, Alito wrote. Accordingly, the Court's decision in Espinoza represented just the first step in rooting out structural injustice against believers and religious organizations.

\section{Bostock}

The final Pandemic Court decision that buttressed religious freedom was Bostock v. Clayton (2020). The Court's ruling in this consolidated case has garnered a sizable amount of public and scholarly attention, both for its landmark extension of LGBTQ rights and for the justices' clash over proper interpretive methods. Not to be overlooked, however, is the extraordinary narrowness of the majority opinion in Bostock and the conspicuous amount of room that different justices carved out for future religious exemptions.

6 Regarding these newer wounds, Thomas cited the Court's recent decisions in Masterpiece Cakeshop v. Colorado Civil Rights Commission (2018) and Obergefell v. Hodges (2015). 
A complex case, which resulted in 168 pages of majority and dissenting opinions, Bostock concerned the inclusion of sexual orientation and gender identity protections within Title VII of the Civil Rights Act of 1964. The Supreme Court was charged with deciding whether Title VII's prohibitions against sex-based employment discrimination meant that employers who discriminated against employees on the basis of sexual orientation and gender identity violated Title VII. Justice Neil Gorsuch, writing on behalf of a six-member majority, determined that sexual orientation and gender identity protections were included within Title VII. For any "employer who fires an individual for being homosexual or transgender fires that person for traits or actions it would not have questioned in members of a different sex. Sex plays a necessary and undisguisable role in the decision, exactly what Title VII forbids" (Gorsuch, p. 2).

The majority acknowledged that the congressmembers who passed the Civil Rights Act in 1964 probably did not believe that sexual orientation and gender identity would be protected under Title VII. However, close examination of both the ordinary public meaning of "sex" and also the development of statutory precedent around the Civil Rights Act supported the conclusion that sexual orientation and gender identity fall under the purview of Title VII (Gorsuch, pp. 2, 4, 12, 24-26).

But Justice Gorsuch's opinion was intentionally narrow, and it left open the possibility of future religious exemptions. Gorsuch understood that religious freedom advocates would worry that Bostock "may require some employers to violate their religious convictions" (Gorsuch, p. 32). Warding off this worry, Gorsuch emphasized the limited reach of Bostock. "We are also deeply concerned with preserving the promise of the free exercise of religion enshrined in our Constitution; that guarantee lies at the heart of our pluralistic society", Gorsuch reassured (Gorsuch, p. 32). Moreover, Justice Gorsuch underlined the religious freedom protections secured by the First Amendment, RFRA, and recent court cases:

This Court has also recognized that the First Amendment can bar the application of employment discrimination laws "to claims concerning the employment relationship between a religious institution and its ministers". Hosanna-Tabor Evangelical Lutheran Church and School v. EEOC, 565 U. S. 171, 188 (2012). And Congress has gone a step further yet in the Religious Freedom Restoration Act of 1993 (RFRA). That statute prohibits the federal government from substantially burdening a person's exercise of religion unless it demonstrates that doing so both furthers a compelling governmental interest and represents the least restrictive means of furthering that interest. Because RFRA operates as a kind of super statute, displacing the normal operation of other federal laws, it might supersede Title VII's commands in appropriate cases. (Gorsuch, p. 32)

In his dissenting opinion, Justice Brett Kavanaugh made sure to reiterate this passage from the majority opinion, in order to stress the religious protections that counterbalanced LGBTQ civil rights gains (Kavanaugh, p. 3). Justice Alito also penned a dissenting opinion in Bostock, which Justice Thomas joined. Alito's dissent methodically articulated a roadmap for religious freedom advocates to use to curtail the application of Bostock. Regardless of whether their challenges pertained to healthcare, or workplace speech, or employment, religious freedom advocates now had a clear guide for future litigation (Alito, pp. 48-53).

\section{Conclusions}

After the Supreme Court's 2019-2020 term concluded, conservative law professor Michael McConnell composed another New York Times article (McConnell 2020). In this article, "On Religion, the Supreme Court Protects the Right to Be Different", McConnell praised the pragmatism, moderation, and thoughtfulness of the Supreme Court. Across a host of cases, the justices had demonstrated their investment in "protecting pluralismthe right of individuals and institutions to be different, to teach different doctrines, to dissent from dominant cultural norms and to practice what they preach" (McConnell 2020). McConnell's upbeat coda represented a stark contrast to his earlier writing. Although 
initially fearful about the weakening of religious freedom during the pandemic, the passage of a few months had left McConnell quite comforted and pleased by the common sense of the Pandemic Court.

The basis for this change of tune is obvious. Religious freedom advocates became political beneficiaries of the rise of COVID-19 in the United States, due to the efforts of the Pandemic Court. At first glance, Little Sisters of the Poor, Our Lady of Guadalupe, Espinoza, and Bostock may appear unrelated to the pandemic. None of these decided cases are inherently related to COVID-19; the facts of all four cases do not pertain to coronavirus in any way. However, these four cases have vital linkages to the pandemic, even if some would argue that these linkages are unconscious or accidental. The decisions in all four of these cases were handed down while the pandemic was raging across the United States. The Court's rulings echoed (and addressed) prominent religious concerns raised during the pandemic, and the impact of these cases is likely to compound the suffering caused by the pandemic.

To be clear, these legal developments do not represent a COVID-19-inspired conspiracy or coordinated religious takeover; religious freedom advocates pushed these cases and rallied around their core causes for years before the Supreme Court granted certiorari and before COVID-19 was detected in the United States. Instead, these legal developments show how the heightened material stakes of expanding religious freedom converged with the parochialism of religious freedom advocates and the Pandemic Court. ${ }^{7}$ This imbalance has the frightening potential to exacerbate and lengthen Americans' hardships.

In Little Sisters of the Poor, Our Lady of Guadalupe, Espinoza, and Bostock, the Court effectively immunized the flock by rewriting the boundaries of religious freedom to further protect religious adherents, institutions, and practices. Meanwhile, millions of Americans were struggling to find or keep a job, to gain or maintain reliable healthcare, and to adjust to new educational changes and learning costs created by the pandemic. The Pandemic Court compounded those struggles, by vindicating religious freedom claims that can hamper the provision of employment, healthcare, and education across the country.

With the recent death of Justice Ruth Bader Ginsburg - and the whirlwind confirmation of the rightwing Amy Coney Barrett to the high court-religious freedom advocates have already begun celebrating their improved political fortunes (Boorstein 2020; Olsen 2020; McConnell and Raskin 2020b). And with more religious freedom cases appearing on the Supreme Court's 2020-21 docket, there is no reason to expect the Court's immunization work to slow down. In fact, the Court has already indicated its desire to pick up where it left off last term (Roman Catholic Diocese of Brooklyn, New York v. Cuomo 2020).

Funding: This research received no external funding.

Institutional Review Board Statement: Not applicable.

Informed Consent Statement: Not applicable.

Data Availability Statement: All data are contained within the article and corresponding references.

Conflicts of Interest: The author declares no conflict of interest.

\section{References}

Armour, Stephanie. 2020. Hospitals' Covid-19 Policies Face Religious-Rights Checks by Trump Administration. The Wall Street Journal, August 10.

Baumgardner, Paul, and Brian K. Miller. 2019. Moving From the Statehouses to the State Courts? The Post-RFRA Future of State Religious Freedom Protections. Albany Law Review 82: 1385-1410.

Bennett, Daniel. 2017. Defending Faith: The Politics of the Christian Conservative Legal Movement. Lawrence: University of Kansas Press. Boorstein, Michelle. 2020. Religious conservatives hopeful new Supreme Court majority will redefine religious liberty precedents. The Washington Post, November 3.

7 These findings are consistent with research conducted within the American political development (APD) subfield of political science, especially APD scholarship that details how even unconscious and contingent alignments of actors, agendas, and temporal opportunities can generate profound and durable political outcomes. See (Pierson 2004; Orren and Skowronek 2004; Staszak 2015). 
Bostock v. Clayton. 590 U.S. on 14 February 2021). 2020. Available online: https://www.supremecourt.gov/opinions/19pdf/17-1618_hfci.pdf (accessed

Calvary Chapel Dayton Valley v. Steve Sisolak, Governor of Nevada; et al. 591 U.S.

2020. Available online: https://www.supremecourt. gov /opinions/19pdf/19a1070_0811.pdf\#page=13. (accessed on 14 February 2021).

Espinoza v. Montana Department of Revenue, 591 U.S. _. 2020. Available online: https://www.supremecourt.gov/opinions/19pdf/18 -1195_g314.pdf (accessed on 14 February 2021).

Galus, Jeremiah. 2020. A New Wave of Government Officials Treating Churches Unconstitutionally. Alliance Defending Freedom. May 29. Available online: https://www.adflegal.org/blog/new-wave-government-officials-treating-churches-unconstitutionally (accessed on 14 February 2021).

Gearan, Anne, Lena H. Sun, Josh Dawsey, and Michelle Boorstein. 2020. Trump tells states to let houses of worship open, sparking cultural and political fight over pandemic restrictions. The Washington Post, May 22.

Hollis-Brusky, Amanda, and Joshua C. Wilson. 2020. Separate But Faithful: The Christian Right's Radical Struggle to Transform Law E Legal Culture. New York: Oxford University Press.

Hosanna-Tabor Evangelical Lutheran Church and School v. Equal Employment Opportunity Commission, 565 U.S. 171. 2012. Available online: https: / / www.supremecourt.gov/opinions/11pdf/10-553.pdf (accessed on 14 February 2021).

Jacobson v. Massachusetts, 197 U.S. 11. 1905. Available online: https://tile.loc.gov/storage-services/service/11/usrep/usrep197/usrep1 97011/usrep197011.pdf (accessed on 14 February 2021).

Kennedy, Duncan. 1986. Freedom and Constraint in Adjudication: A Critical Phenomenology. Journal of Legal Education 36: 518-62.

Kirk, Charlie. 2020. Will Christians Stand Up Against a Godless Kentucky Government? Newsweek. April 12. Available online: https: / / www.newsweek.com/charlie-kirk-will-christians-stand-against-godless-kentucky-government-opinion-1497475 (accessed on 14 February 2021).

Lewis, Andrew R. 2017. The Rights Turn in Conservative Christian Politics: How Abortion Transformed the Culture Wars. New York: Cambridge University Press.

Little Sisters of the Poor Saints Peter and Paul Home v. Pennsylvania, 591 U.S. _. 2020. Available online: https://www.supremecourt. gov/opinions/19pdf/19-431_5i36.pdf (accessed on 14 February 2021).

Locke v. Davey, 540 U. S. 712. 2004. Available online: https:/ / www.supremecourt.gov/opinions/03pdf/02-1315.pdf (accessed on 14 February 2021).

Masterpiece Cakeshop v. Colorado Civil Rights Commission, 584 U.S. __. 2018. Available online: https://www.supremecourt.gov/ opinions /17pdf/16-111_j4el.pdf (accessed on 14 February 2021).

McConnell, Michael, and Max Raskin. 2020a. If Liquor Stores Are Essential, Why Isn't Church? The New York Times, April 21.

McConnell, Michael, and Max Raskin. 2020b. The Supreme Court Was Right to Block Cuomo's Religious Restrictions. The New York Times, December 1.

McConnell, Michael. 2020. On Religion, the Supreme Court Protects the Right to Be Different. The New York Times, July 9.

Obergefell v. Hodges, 576 U.S. 644. 2015. Available online: https://www.supremecourt.gov/opinionsd/14pdf/14-556_3204.pdf (accessed on 14 February 2021).

Olsen, Henry. 2020. The Supreme Court finally has a majority that will protect religious freedom. The Washington Post, November 27.

Orren, Karen, and Stephen Skowronek. 2004. The Search for American Political Development. New York: Cambridge University Press.

Our Lady of Guadalupe School v. Morrissey-Berru, 591 U.S. __. 2020. Available online: https:/ / www.supremecourt.gov/opinions /19 pdf/19-267_1an2.pdf (accessed on 14 February 2021).

Parke, Caleb. 2020. Trump slams Dem governors for unfair treatment of churches during coronavirus. Fox News. May 22. Available online: https:/ / www.foxnews.com/politics/trump-coronavirus-dem-governors-church-essential-open (accessed on 14 February 2021).

Perkins, Tony. 2020. Religious liberty during COVID-19: Get a haircut, but stay away from church. The Washington Times, May 21.

Pierson, Paul. 2004. Politics in Time: History, Institutions, and Social Analysis. Princeton: Princeton University Press.

Posner, Sarah. 2020. From St. John's Episcopal Church to pandemic response, Trump co-opts religion to woo the religious right. NBC News, June 2.

Reno, R. R. 2020. Say 'No' To Death's Dominion. First Things, March 23.

Roman Catholic Diocese of Brooklyn Roman Catholic Diocese of Brooklyn, New York v. Andrew M. Cuomo, Governor of New York (2020) Roman Catholic Diocese of Brooklyn, New York v. Andrew M. Cuomo, Governor of New York, 592 U.S. https:/ / www.supremecourt.gov/opinions/20pdf/20a87_4g15.pdf (accessed on 14 February 2021).

Schmitz, Matthew. 2020. Church as a Non-Essential Service. First Things, March 27.

Sitman, Matthew. 2020. Why the Pandemic Is Driving Conservative Intellectuals Mad. The New Republic, May 21.

South Bay United Pentecostal Churc; et al. v. Gavin Newsom, Governor of California; et al. 590 U.S. _. 2020. Available online: https:/ / www.supremecourt.gov/opinions/20pdf/20a136_bq7c.pdf (accessed on 14 February 2021).

Staszak, Sarah. 2015. No Day in Court: Access to Justice and the Politics of Judicial Retrenchment. New York: Oxford University Press.

United States Department of Justice, Office of Public Affairs. 2020. Attorney General William P. Barr Issues Statement on Religious Practice and Social Distancing; Department of Justice Files Statement of Interest in Mississippi Church Case. Washington, DC, USA: United States Department of Justice, Office of Public Affairs, April 14.

Vermeule, Adrian. 2020. Beyond Originalism. The Atlantic, March 31. 
Waltman, Jerold. 2019. Church and State in the Roberts Court: Christian Conservatism and Social Change in Ten Cases, 2005-2018. Jefferson: McFarland.

Zubik v. Burwell, 578 U.S. _. 2016. Available online: https://www.supremecourt.gov/opinions/15pdf/14-1418_8758.pdf (accessed on 14 February 2021). 